STUDIA I ARTYKUEY 



\section{KONCEPCJA PODATKU TURYSTYCZNEGO NAKŁADANEGO WE WŁosZeCH}

\section{Uwagi ogólne}

W Polsce daninami nakładanymi na osoby, które nie zamieszkują na terenie danej miejscowości, mogą być: opłata miejscowa albo opłata uzdrowiskowa ${ }^{1}$. Co do zasady powyższe opłaty nakładane są na osoby fizyczne, które przebywają w danej miejscowości dłużej niż jedną dobę. Należy jednak zauważyć, że przyjęta przez polskiego ustawodawcę koncepcja opodatkowania dwoma powyższymi daninami nie jest idealna, co powoduje, że fiskalnie nie są efektywne. W głównej mierze za powyższy stan rzeczy odpowiadają wadliwie skonstruowane przepisy ustawy o podatkach i opłatach lokalnych. W literaturze przedmiotu ${ }^{2}$ oraz wśród przedstawicieli samorządu ${ }^{3}$ coraz częściej postuluje się wprowadzenie zmian. Niejednokrotnie wskazuje się na potrzebę oparcia konstrukcji polskich opłat na istniejących już koncepcjach przyjętych w państwach Europy Zachodniej. Nie ulega wątpliwości, że polskie daniny nakładane

* Dr, Katolicki Uniwersytet Lubelski Jana Pawła II; e-mail: mburzec@kul.pl, ORCID ID: https:/ / orcid.org/0000-0003-3886-0068.

1 Art. 17 ustawy z dnia 12 stycznia 1991 r. o podatkach i opłatach lokalnych, tekst jednolity: Dz. U. z 2019 r. poz. 1170.

2 Zob. M. Burzec, Optata miejscowa jako danina nakładana na turystów, „Samorząd Terytorialny" 2019, nr 6, s. 83-93; G. Kasprzak, Zastapienie optaty miejscowej optata turystyczna postulaty "de lege ferenda”, „Przegląd Podatków Lokalnych i Finansów Samorządowych” 2017, nr 8, s. 6 i nast.

3 Zob. R. Krupa-Dąbrowska, W Polsce danina jak we Włoszech, „Rzeczpospolita” z dnia 27 marca 2018 r. (dodatek Życie Regionów), https://regiony.rp.pl/archiwum/5338-w-polsce-danina-jak-we-wloszech [dostęp: 1.04.2019 r.]. 
na turystów wymagają wprowadzenia koniecznych zmian. W związku z powyższym, celem niniejszego artykułu - w którym poruszona została problematyka konstrukcji podatku turystycznego we Włoszech - jest wskazanie możliwości takiego ukształtowania elementów konstrukcyjnych opłaty miejscowej oraz uzdrowiskowej, aby w przyszłości stanowiły one efektywny instrument fiskalny. Niniejsze opracowanie powinno się zatem wpisać w dyskurs dotyczący przyszłości powyższych obciążeń. Na marginesie wyjaśnić należy, że włoska nazwa omawianej daniny brzmi imposta di soggiorno, co literalnie należałoby przetłumaczyć jako podatek od pobytu. Nie jest jednak błędem użycie, tak jak ma to miejsce w artykule, nazwy podatek turystyczny. Wydaje się ona bardziej adekwatna do omawianego zagadnienia. W opracowaniu przedstawione zostały regulacje prawne obowiązujące na Półwyspie Apenińskim od momentu wprowadzenia w życie pierwszej daniny obciążającej turystów do czasów nam współczesnych. Podkreślić jednak należy, że ramy formalne opracowania nie pozwalają na pogłębioną analizę wszystkich zagadnień związanych z obciążeniem daninowym turystów. Problematyka podatków turystycznych nakładanych przez regiony cieszące się autonomią - takie jak Sardynia oraz region i prowincje Trydentu-Górnej Adygi - zostały jedynie zasygnalizowane. Opracowanie oparte zostało, w głównej mierze, na krajowych, regionalnych oraz prowincjonalnych (Bolzano, Trydent) aktach prawnych. Ponadto przeanalizowanych zostało kilkadziesiąt uchwał włoskich rad gmin. Z uwagi na ich dużą liczbę (we Włoszech prawie każda miejscowość posiada status gminy), a także ze względu na ramy formalne artykułu, ograniczono się jedynie do uchwał tych gmin, które posiadają status tzw. stolic regionu, miast będących siedzibą prowincji oraz miejscowości cieszących się powszechnym uznaniem turystów.

\section{Historia podatku turystycznego we Włoszech}

Po raz pierwszy danina nakładana na turystów ustanowiona została we Włoszech pod koniec $1910 \mathrm{r}$. Była nią opłata turystyczna (tassa di soggiorno $)^{4}$, a uprawnionymi do jej poboru były gminy, na terenie których

4 Legge 11 dicembre 1910, n. 863, che dà facoltà ai Comuni di istituire una tassa di soggiorno, Gazzetta Ufficiale n. 294 del 20 dicembre 1910, n. 294 (dalej: L. 11 dicembre 1910, n. 863). 
istotne znaczenie gospodarcze odgrywał fakt umiejscowienia zakładu hydroterapeutycznego czy posiadania statusu ośrodka klimatycznego lub kąpielowego. Opłata miała charakter celowy. Uzyskiwane z niej dochody mogły być przeznaczone wyłącznie na wydatki zmierzające do rozwoju miejscowości posiadających status kurortów nadmorskich lub klimatyczno-uzdrowiskowych. Cel ten był spełniany także, gdy uzyskane z niej dochody przeznaczane były na podniesienie walorów estetycznych danej miejscowości ${ }^{5}$. Maksymalną wysokość opłaty wskazywała ustawa, natomiast rady gmin $\mathrm{w}$ drodze uchwały określały wysokości stawek. Sama opłata mogła być pobierana jedynie od tych osób, które zamieszkiwały na terenie danej miejscowości powyżej $5 \mathrm{dni}$. W konstrukcji daniny przewidziano ulgi polegające na obniżeniu opłaty o $50 \%$, w stosunku do dzieci poniżej 12 roku życia oraz osób zatrudnionych jako służba domowa.

Pod koniec lat 30. XX w. opłata turystyczna (tassa di soggiorno) zastąpiona została podatkiem turystycznym (imposta di soggiorno). Jego konstrukcja $\mathrm{w}$ prawie niezmienionej formie przetrwała do końca lat 80 . ubiegłego wieku' . W literaturze przedmiotu istnienie powyższego ciężaru publicznoprawnego uzasadniano tym, że gmina zobligowana jest do ponoszenia określonych wydatków nie tylko na rzecz swoich stałych mieszkańców, ale także tych, którzy zamieszkiwali na jej terenie czasowo. W ówczesnym systemie podatkowym mieszkańcy będący rezydentami obciążeni byli podatkiem od wartości czynszowej (imposta sul valor locativo) ${ }^{7}$ natomiast osoby przebywające czasowo - podatkiem turystycznym (imposta di soggiorno). Wskazywano jednak, że podstawa do nałożenia obu danin jest taka sama - wydatkowanie osobistego dochodu przez podatnika na cele mieszkalne ${ }^{8}$.

Przepisy włoskiego prawa przewidywały dwie sytuacje, które prowadziły do powstania obowiązku podatkowego. Pierwszą z nich był fakt tymczasowego zakwaterowania $\mathrm{w}$ hotelach, pensjonatach, gospodach, zakładach oraz domach opieki zdrowotnej; drugą - zamieszkanie przez okres dłuższy niż pięć dni w willach, apartamentach, umeblowanych

5 Art. 2 L. 11 dicembre 1910, n. 863.

6 Regio Decreto-Legge 24 novembre 1938, n. 1926, Modificazioni concernenti l'ordinamento della imposta di soggiorno, di cura e turismo, Gazzetta Ufficiale n. 297 del 29 dicembre 1938 (dalej: ustawa z 1938 r.); szerzej zob. E. Morselli, Sistema tributario Italiano. L'ordinamento delle imposte, Padova 1939, s. 241; tenże, Le imposte in Italia, Padova 1956, s. 370.

7 Danina ta została zniesiona dopiero w latach 70. ubiegłego wieku.

8 L. Einaudi, Il sistema tributario italiano, Torino 1939, s. 294. 
pokojach lub innych miejscach zakwaterowania9. Wysokość podatku uzależniona została od liczby dni spędzonych przez osobę w danej miejscowości oraz kategorii lokalu. W tym celu włoski ustawodawca podzielił lokale noclegowe na dwie grupy. Do pierwszej zaliczono: hotele, pensjonaty, zajazdy, domy opieki oraz domy zdrowia. W ramach powyższej grupy wyodrębniono dodatkowo sześć kategorii (od A do F). W praktyce podatek turystyczny dla osób przebywających w powyższych obiektach pobierany był przez 30 dni, gdyż osoby zamieszkujące nieustannie przez ten okres zwalniane były z podatku przez następne 90 dni. Do drugiej grupy zaliczono: wille, apartamenty, umeblowane pokoje i inne miejsca noclegowe. Obiekty te podzielono na cztery kategorie. Podatek obowiązywał za cały okres pobytu w danej miejscowości, o ile nie przekraczał 120 dni licząc od dnia przybycia.

Wysokość daniny mogła zostać obniżona o 50\%, gdy podatnikiem była: osoba zatrudniona jako służba domowa; dziecko do 12 roku życia; dziecko z rodziny wielodzietnej (powyżej 5 dzieci) pozostające na utrzymaniu rodziców; uczestnik zorganizowanej grupy szkolnej liczącej co najmniej 15 osób. Ulga w wysokości 25\% stosowana była do uczestników wycieczek pracowniczych liczących co najmniej 15 osób. Ustawa z 1938 r. zawierała szeroki katalog zwolnień, które miały zastosowanie m.in. w stosunku do: dzieci do 3 lat; inwalidów wojennych; duchownych odbywających posługę kapłańską; przedstawicieli placówek dyplomatycznych obcych państw; osób przebywających w szpitalach; osób pobierających naukę na terenie miejscowości; przebywających w celach zarobkowych; podatników podatku od wartości czynszowej oraz ich małżonków, bliskich krewnych oraz krewnych do 3 stopnia, a także ich służby domowej ${ }^{10}$.

Podatek przestał obowiązywać z dniem 1 stycznia 1989 r. ${ }^{11} \mathrm{~W}$ związku z organizacją przez Włochy Mistrzostw Świata w piłce nożnej w 1990 r. powstała obawa, że istnienie daniny negatywnie wpłynie na rozwój turystyki $^{12}$.

9 Art. 1 ustawy z 1938 r.

10 Zob. art. 5 ustawy z 1938 r.

11 Art. 10 ust. 1 Decreto-Legge 2 marzo 1989, n. 66, Disposizioni urgenti in materia di autonomia impositiva degli enti locali e di finanza locale, Gazzetta Ufficiale n. 51 del 2 marzo 1989.

12 Na marginesie należy podnieść, że stosownie do przepisów Konstytucji Włoch, niektóre z włoskich regionów posiadają autonomię, która przejawia się między innymi możliwością ustanawiania własnych danin. Warunkiem jest jednak to, aby nakładane przez 


\section{Imposta di soggiorno jako nowy - stary podatek nakładany na turystów we Włoszech}

Włochy bardzo boleśnie odczuły skutki kryzysu gospodarczego z 2008 r. Odpowiedzią na taki stan rzeczy była próba sanacji finansów publicznych, co miało nastąpić m.in. poprzez wdrożenie popularnej w owym czasie, wśród polityków oraz przedstawicieli doktryny prawa finansowego, koncepcji tzw. federalizmu fiskalnego. Należy jednak zauważyć, że struktura administracyjna Włoch, pomimo występowania regionów

region daniny były zharmonizowane z centralnym systemem podatkowym, np.: art. 12 Legge costituzionale 26 febbraio 1948, n. 4, Statuto speciale per la Valle D’Aosta, Gazzetta Ufficiale n. 59 del 10 marzo 1948; art. 51 Legge costituzionale 31 gennaio 1963, n. 1, Statuto speciale della Regione autonoma Friuli Venezia Giulia, Gazzetta Ufficiale n. 29 del 1 febbraio 1963; art. 73 Dectreto del Presidente della Repubblica 31 agosto 1972, n. 670: Approvazione del testo unico delle leggi costituzionali concernenti lo statuto speciale per il Trentino-Alto Adige, Gazzetta Ufficiale n. 301 del 20 novembre 1972. Na tej podstawie autonomiczny region Sardynii w 2008 r. umożliwił gminom nakładanie podatku turystycznego na osoby fizyczne niebędące mieszkańcami regionu, które przebywały tam w trakcie sezonu turystycznego trwającego od 15 czerwca do 15 września, zob. art. 18 Legge Regionale 29 maggio 2007, n. 2, Disposizioni per la formazione del bilancio annuale e pluriennale della Regione (legge finanziaria 2007), Bollettino Ufficiale della Regione Sardegna n. 18 del 31 maggio 2007, Supplemento Ordinario n. 2, a także B. Biagi, M.G. Brandano, M. Pulina, La tassazione turistica: il caso della Sardegna, [w:] V. Ficari, G. Scanu (red.), "Tourism Taxation" sostenibilità ambientale e turismo fra fiscalità locale e competitività, Torino 2013, s. 37 i nast. Wcześniej, w latach 2006-2008, Sardynia nakładała regionalny podatek od cumowania (imposta sugli ormeggi). Obciążał on cumujące w okresie od 1 czerwca do 30 września łodzie/statki o długości powyżej $14 \mathrm{~m}$ w wyznaczonych miejscach położonych na terenie Sardynii. Jego wysokość uzależniona była od długości obiektu pływającego, zob. art. 4 Legge Regionale 11 maggio 2006, n. 4, Disposizioni varie in materia di entrate, riqualificazione della spesa, politiche sociali e di sviluppo, Bollettino Ufficiale della Regione Sardegna n. 15 del 13 maggio 2006. Regionalny podatek turystyczny od drugiej połowy lat 70. nakładany był także w prowincjach Bolzano i Trydentu, które to wchodzą w skład regionu Trydent-Górna Adyga, zob. Legge Regionale 29 agosto 1976, n. 10. Disciplina dell'imposta di soggiorno, Bollettino Ufficiale n. 46 del 26 ottobre 1976; G. Ielo, Il federalismo fiscale municipale, Milano 2011, s. 46-51. Natomiast od 1 stycznia 2014 r. w prowincji Bolzano oraz od 1 listopada 2015 r. w prowincji Trydent wprowadzone zostały nowe podatki turystyczne, które mogą być pobierane przez gminy wchodzące w skład powyższych jednostek administracyjnych, zob. art. 1 Legge Provinciale 16 maggio 2012, n. 9, Finanziamento in materia di turismo, Gazzetta Ufficiale 3 Serie Speciale - Regioni n. 25 del 30 giugno 2012; art. 16 bis Legge Provinciale 11 giugno 2002, n. 8, Disciplina della promozione turistica in provincia di Trento, Bollettino Ufficiale n. 27 del 25 giugno 2002. 
o statucie specjalnym, zbliżona jest jednak do państwa unitarnego. Wprowadzenie typowego modelu charakterystycznego dla państw federalnych nie było zatem możliwe ${ }^{13}$. Włoski model federalizmu fiskalnego ograniczył się więc do zmniejszenia roli transferów pieniężnych pochodzących z budżetu państwa, kierowanych do jednostek samorządu terytorialnego, przy jednoczesnym zwiększeniu przez nie dochodów z podatków własnych oraz udziałów w podatkach państwowych. W celu zapewnienia minimalnego poziomu świadczonych usług publicznych przez jednostki samorządowe, różnice wynikające z ograniczeń fiskalnych poszczególnych regionów, prowincji lub gmin zostały zniwelowane przez odpowiednie mechanizmy wyrównawcze. Podstawową istotą włoskiej wersji federalizmu fiskalnego było pozostawienie na terenie danej jednostki samorządu terytorialnego dochodów podatkowych tej społeczności lokalnej, która je wygenerowała ${ }^{14}$. Koncepcja ta w głównej mierze odnosiła się do finansów regionalnych. Należy jednak zauważyć, że także w stosunku do najniższego szczebla samorządu terytorialnego w 2011 r. uchwalona została ustawa, dzięki której gminom przekazano instrumenty zmierzające do uzyskania nowych dochodów ${ }^{15}$. Jednym $z$ nich było ponowne wprowadzenie fakultatywnego podatku turystycznego (imposta di soggiorno) ${ }^{16}$. W prakty-

13 Podkreślić należy, że na drodze ku federalizmowi fiskalnemu skutecznie stał włoski Trybunał Konstytucyjny.

${ }_{14}$ Szerzej na temat federalizmu fiskalnego zob. F. Gallo, I principi fondamentali di coordinamento del sistema tributario nel federalismo fiscale, [w:] A. Uricchio (red.), Federalismo fiscale: evoluzione e prospettive, Bari 2013, s. 27 i nast.; A. Uricchio, Il federalismo della crisi o la crisi del federalismo? Dalla legge delega 42/2009 ai decreti attuativi e alla manovra Salva Italia, Bari 2012, s. 159 i nast.; A. Giovannini, Sul federalismo fiscale che non c'è, „Diritto e Pratica Tributaria" 2012, t. 83, nr 6, s. 1305 i nast.

15 Decrecto Legislativo 14 marzo 2011, n. 23, Disposizioni in materia di federalismo Fiscale Municipale, Gazzetta Ufficiale n. 67 del 23 marzo 2011 (dalej: ustawa z 2011 r.).

16 Podnieść należy, że ustawa z 2011 r. nie regulowała kwestii nakładania podatku turystycznego w Rzymie. Wskazać bowiem należy, że powyższa danina w stolicy Włoch nakładana jest na podstawie art. 14 ust. 16 lit. e Decreto-Legge 31 maggio 2010, n. 78 Misure urgenti in materia di stabilizzazione finanziaria e di competitività economica, Gazzetta Ufficiale n. 176 del 30 luglio 2010. Na podstawie powyższego aktu prawnego istnieje możliwość wprowadzenia przez Rzym podatku turystycznego, przy czym maksymalna kwota podatku za jedną noc nie może przekroczyć 10 euro. Wysokość podatku może być różnicowana $\mathrm{w}$ zależności od rodzaju obiektu noclegowego. Podatek turystyczny wprowadzony został przez gminę Rzym z dniem 1 stycznia 2011 r. Aktualną podstawą prawną do nakładania powyższej daniny jest: Regolamento sul Contributo di Soggiorno nella Città di Roma, approvato con deliberazione dell'Assemblea Capitolina n. 32 del 30 marzo 2018, 
ce jest to aktualnie jedyna danina publiczna, w stosunku do której gminom przyznano tak szerokie władztwo podatkowe w zakresie kształtowania jej poszczególnych elementów konstrukcyjnych. Przysługujące gminom władztwo wpisuje się w standardy sformułowane w art. 119 Konstytucji Republiki Włoskiej z dnia 27 grudnia 1947 r. ${ }^{17}$

W ustawie z 2011 r. w sposób ramowy określono zasady nakładania podatku od turystów. Stosownie do przyjętych regulacji podmiotami czynnymi mogą być jedynie: gminy, będące siedzibą prowincji; związki gmin; gminy wpisane na regionalną listę miejscowości turystycznych oraz tzw. miasta sztuki (città d'arte). Podmiotami biernymi są osoby fizyczne, które przebywają w obiektach służących zakwaterowaniu. Podkreślić należy, że poszczególne gminy $\mathrm{w}$ drodze uchwały mają prawo do doprecyzowania zakresu przedmiotowego omawianej daniny. Ustawa z 2011 r. określiła maksymalną wysokość podatku, która nie może przekroczyć 5 euro za noc. Ustawodawca dopuścił jednak możliwość różnicowania wysokości podatku proporcjonalnie do standardu obiektu służącego zakwaterowaniu. Wprowadzona danina ma charakter podatku celowego, a uzyskiwany z niej dochód przeznaczany jest na finansowanie inwestycji turystycznych, utrzymania lokalnych dóbr kultury i środowiska, a także związanych z nimi lokalnych usług świadczonych przez organy publiczne.

Wskazać należy, że podatnikami podatku turystycznego mogą być osoby fizyczne, które przebywają na terenie gminy w obiektach służących zakwaterowaniu. Jednakże nie każda osoba fizyczna, która korzysta z noclegu w takich obiektach stanie się podatnikiem. Wynika to z samej koncepcji omawianej daniny. Przypomnieć należy, że jej celem jest obciążenie jedynie tych osób, które nie ponoszą na co dzień ciężarów utrzymania infrastruktury komunalnej. Stąd też z zakresu podmiotowego wyłączone zostały osoby, które partycypują w daninach zasilających budżet gminy. We Włoszech powyższy problem rozwiązano w ten sposób, że podatnikami mogą być jedynie osoby niemające stałego miejsca zamieszkania na terytorium gminy. W uchwałach podejmowanych przez rady gminy odnaleźć można trzy sposoby regulacji prawnych określających podatnika podatku

\footnotetext{
http://www.cnaroma.it/sites/default/files/delibera_tassa_soggiorno_n.32-2018.pdf [dostęp: 1.04.2019 r.].

17 Konstytucja Republiki Wtoskiej z 27 grudnia 1947 roku, [w:] Z. Witkowski (tłum.), Konstytucja Wtoch, Warszawa 2004.
} 
turystycznego. Pierwszy, polega na wskazaniu w uchwale, że podatnikami są osoby fizyczne niebędące rezydentami (sytuacja taka ma miejsce m.in. w Bolonii ${ }^{18}$, Catanzaro ${ }^{19}$, Florencji $^{20}$, Genui ${ }^{21}$, Neapolu ${ }^{22}$, Rawennie ${ }^{23}$ ). Drugi, polega na tym, że w uchwałach zawiera się sformułowanie wskazujące, że podatnikami są osoby fizyczne, które nie zostały wpisane do rejestru ludności danej gminy (np. Taorminie ${ }^{24}$, Turynie ${ }^{25}$ ). Z praktycznego punktu widzenia powyższa różnica ma jedynie znaczenie semantyczne, gdyż zgodnie z włoskim prawem o tym kto jest rezydentem na terenie danej gminy decyduje wpis do rejestru ludności (l'anagrafe della popolazione

18 Regolamento dell'imposta di soggiorno nel Comune di Bologna, approvato con deliberazione del Consiglio Comunale n. 174 del 21 maggio 2012, http:// www.comune.bologna.it/media/files/regolamento_imposta_di_soggiorno_odg_174_2012.pdf; dostęp: 1.04.2019 r. (dalej: uchwała Bolonii).

19 Regolamento comunale per l'istituzione dell'imposta di soggiorno, approvato con deliberazione del Consiglio Comunale n. 125 del 30 ottobre 2017, https:// www.comune.catanzaro.it/ambiente/turismo/tassa-di-soggiorno/; dostęp: $1.04 .2019 \mathrm{r}$. (dalej: uchwała Catanzaro).

20 Regolamento dell'imposta di soggiorno nella Città di Firenze, approvato con deliberazione del Consiglio Comunale n. 33 del 20 giugno 2011 con modificazioni, http:/ / centroservizi.lineacomune.it/immagini/images/IMPOSTASOGGIORNO/firenze-1giugno/Regolamento_giugno2012.pdf; dostęp: 1.04.2019 r. (dalej: uchwała Florencji).

21 Regolamento dell'imposta comunale di soggiorno nella Città di Genova, approvato con deliberazione del Consiglio Comunale n. 5 del 7 febbraio 2012 con modificazione, https://smart.comune.genova.it/system/files/regolamenti/reg_imposta_soggiorno_ 2017_con_link_.pdf; dostęp: 1.04.2019 r. (dalej: uchwała Genui).

${ }^{22}$ Testo coordinato del Regolamento sull'imposta di soggiorno, approvato con deliberazione del Consiglio Comunale n. 20 del 21 giugno 2012 con modificazioni, http:/ / www.comune.napoli.it/flex/cm/pages/ServeBLOB.php/L/IT/IDPagina/981; dostęp: 1.04.2019 r. (dalej: uchwała Neapolu).

23 Regolamento per l'applicazione dell'imposta di soggiorno, approvato con deliberazione del Consiglio Comunale n. 166 del 20 dicembre 2018, http://www.ravennaentrate.com /upload/Regolamento_delibera_CC_166_del_20-12-2018.pdf; dostęp: 1.04.2019 r. (dalej: uchwała Rawenny).

${ }^{24}$ Regolamento dell'imposta di soggiorno nel Comune di Taormina, approvato con deliberazione del Consiglio Comunale n. 80 del 6 novembre 2012, http: //www.comune.taormina.me.it/aree-tematiche/informazioni/imposta-di-soggiorno/ pdf/regolamento-tassa-di-soggiorno-taormina.pdf; dostęp: 1.04.2019 r. (dalej: uchwała Taorminy).

25 Regolameto per l'applicazione dell'imposta di soggiorno, approvato con deliberazione del Consiglio Comunale n. 349 del 27 febbraio 2012, http:/ / www.comune.torino.it/ regolamenti/349/349.htm; dostęp: 1.04.2019 r. (dalej: uchwała Turynu). 
residente $)^{26}$. W uchwałach włoskich gmin znajduje się także trzeci sposób określający zakres podmiotowy. Polega on na tym, że uchwała stanowi, iż podatnikiem jest osoba fizyczna korzystająca z noclegu na terenie gminy, jednocześnie w katalogu zwolnień podatkowych wskazuje się te podmioty, które są wpisane do rejestru ludności (sytuacja taka ma miejsce np. w Amalfi ${ }^{27}$, Lecce ${ }^{28}$, Wenecji ${ }^{29}$, Weronie ${ }^{30}$ ). Na marginesie podnieść należy, że nie wszystkie włoskie gminy w sposób prawidłowy, z punktu widzenia techniki legislacyjnej, redagują przepisy zawarte $w$ uchwałach. Znaleźć można bowiem regulacje, gdzie w jednym z artykułów uchwały odnoszącym się do zakresu podmiotowego ustala się, że podatnikiem omawianej daniny może być osoba fizyczna, która nie widnieje w spisie ludności danej gminy, by następnie w artykule traktującym o zwolnieniach wymienić jako podmioty zwolnione, te które widnieją w spisie ludności danej gminy ${ }^{31}$.

26 Stosownie do przepisów włoskiego prawa, każda osoba zobligowana jest do uzyskania wpisu do rejestru ludności. Podstawą wpisu jest: urodzenie się, zmiana miejsca zamieszkania spowodowana przeprowadzką z innej gminy bądź z innego państwa, zob. Decreto del Presidente della Repubblica 30 maggio 1989, n. 223, approvazione del nuovo regolamento anagrafico della popolazione residente, Gazzetta Ufficiale n. 132 del 8 giugno 1989.

27 Regolamento per l'applicazione dell'imposta di soggiorno, approvato con deliberazione del Consiglio Comunale n. 29 del 29 settembre 2014, https:/ /www.amalfi.gov.it/ wp-content/uploads/2014/10/Regolamento-per-lapplicazione-dellImposta-di-Soggiorno.pdf; dostęp: 1.04.2019 r. (dalej: uchwała Amalfi).

28 Regolamento comunale per l'applicazione dell'imposta di soggiorno, approvato con deliberazione del Consiglio Comunale n. 55 del 1 agosto 2012, https:/ / www.comune.lecce.it /docs/default-source/regolamenti-comunali/triuti-e-fiscalit\%c3\%a0-locale/regolamento-imposta-di-soggiorno-d-c-c-64_2018.pdf?sfvrsn=ee0fc0a8_8; dostęp: 1.04.2019 r. (dalej: uchwała Lecce).

29 Regolamento dell'imposta di soggiorno nella Città di Venezia, allegato alla deliberazione di consiglio Comunale n. 57 del 19 dicembre 2018, https://www.comune.venezia.it/ sites/comune.venezia.it/files/page/files/57_B\%20Regolamento\%20Imposta \%20soggiorno.pdf; dostęp: 1.04.2019 r. (dalej: uchwała Wenecji).

30 Regolamento dell'imposta di soggiorno, approvato con deliberazione del Consiglio Comunale n. 61 del 12 luglio 2012, https://www.comune.verona.it/media//Redazione\%20web/ente_comune/regolamenti/regolamento_imposta_di_soggiorno.pdf; dostęp: 1.04.2019 r. (dalej: uchwała Werony).

31 Sytuacja taka ma miejsce m.in. w Taorminie, zob. art. 2 ust. 1, art. 3 ust. 1 uchwały Taorminy. 
Obowiązek podatkowy w podatku turystycznym powstaje w związ$\mathrm{ku} \mathrm{z}$ pobytem $\mathrm{w}$ formie noclegu $\mathrm{w}$ obiektach służących zakwaterowaniu. Zauważyć przy tym należy, że włoskie gminy korzystają z dwóch sposobów doprecyzowania sformułowania „obiekty służące zakwaterowaniu”. W dużej części uchwał przyjęto odwołanie się do regionalnych aktów prawnych normujących kwestię turystyki (np. w Genui ${ }^{32}$, Mediolanie ${ }^{33}$, Sienie $^{34}$, Rawennie ${ }^{35}$ ). W powyższych aktach obiekty służące zakwaterowaniu zostały podzielone na obiekty hotelowe i pozahotelowe. Do pierwszej grupy zaliczone zostały: hotele, apartamenty hotelowe, zajazdy. Do drugiej przynależą: domy wakacyjne, schroniska, schroniska alpejskie, pokoje do wynajęcia, domki letniskowe i apartamenty, kwatery agroturystyczne, bed and breakfast, tzw. wioski turystyczne (villaggi turistici), kempingi, miejsca postojowe dla kamperów ${ }^{36}$. Alternatywnym sposobem doprecyzowania przedmiotu opodatkowania jest enumeratywne wymienienie $\mathrm{w}$ uchwale obiektów służących zakwaterowaniu (ma to miejsce np. w Catanzaro, Como, Bolonii, Neapolu, Taorminie). Rozwiązanie takie posiada jednak wadę, gdyż brak wyszczególnienia określonego obiektu powoduje, że pobyt $\mathrm{w}$ nim nie będzie rodził obowiązku zapłaty podatku. Z drugiej jednak strony dana gmina może - monitorując przepływy turystów i posiadając w ten sposób dane odnoszące się do ich preferencji noclegowych - doprecyzować pożądany zakres przedmiotowy podatku, tak z punktu widzenia fiskalnego, jak i pozafiskalnego. Sytuacja taka ma miejsce na przykład w Catanzaro, gdzie oprócz powszechnie wykorzystywanych obiektów służących zakwaterowaniu wymieniono dodatkowo religijne domy gościnne, a także pokoje gościnne znajdujące się przy niektórych instytucjach (takich jak np. sądy, uniwersytety, instytuty badawcze,

32 Zob. Legge Regionale 12 novembre 2014, n. 32, Testo Unico in materia di strutture turistico ricettive e norme in materia di imprese turistiche, Bollettino Ufficiale n. 16 del 14 novembre 2014 (dalej: Legge Regionale 12 novembre 2014, n. 32).

33 Legge Regionale 1 ottobre 2015, n. 27, Politiche regionali in materia di turismo e attrattività del territorio lombardo, Bollettino Ufficiale n. 40 del 2 ottobre 2015.

34 Legge Regionale 20 dicembre 2016, n. 86, Testo unico del sistema turistico regionale, Bollettino Ufficiale n. 57 del 28 dicembre 2016.

35 Legge Regionale 28 luglio 2004, n. 16, Disciplina delle strutture ricettive dirette all'ospitalità, Bollettino Ufficiale della regione Emilia-Romagna n. 102 del 28 luglio 2004.

${ }^{36}$ Zob. Legge Regionale 12 novembre 2014, n. 32. 
kliniki itd.) $)^{37}$. Natomiast w Neapolu z obiektów służących zakwaterowaniu wprost wyłączone zostały kempingi ${ }^{38}$.

Ustawa z 2011 r. wprowadziła regulację, że podatek turystyczny pobierany jest za każdą noc spędzoną w obiektach służących zakwaterowaniu. Nie określa jednak maksymalnej liczby nocy spędzonych w danym obiekcie. Z jednej strony, brak jest formalnych ograniczeń do tego, aby podatek turystyczny mógł zostać nałożony za każdy nocleg spędzony w ciągu następujących po sobie $360 \mathrm{dni}$ w roku. Z drugiej jednak strony, skoro ustawa z 2011 r. nie określa maksymalnej liczby noclegów, to nie ma jakichkolwiek przeciwwskazań w tym zakresie, aby materię tę można było uregulować na poziomie aktów prawa miejscowego. W szczególności, że w tradycji włoskich podatków turystycznych istniały limity określające maksymalny czas trwania obowiązku podatkowego. Analizując uchwały włoskich gmin, powyższa kwestia rozstrzygana jest na dwa sposoby. Pierwszy z nich polega na tym, że maksymalna liczba noclegów, za które może być pobierany podatek, została przypisana jedynie do określonego typu obiektów służących zakwaterowaniu. Natomiast w stosunku do pozostałych - podatek płacony jest bez względu na liczbę noclegów podjętych przez podatnika. Rozwiązanie takie przyjęto w Mediolanie, gdzie podatek pobierany jest za cały okres pobytu, z wyjątkiem: rezydencji, domów wczasowych (case per ferie) prowadzonych przez organizacje non profit oraz domów i mieszkań wakacyjnych. W stosunku do powyższych obiektów podatek pobierany jest tylko za pierwsze 14 dni noclegu (pobytu $)^{39}$. Drugim sposobem jest określenie maksymalnej liczby noclegów bez względu na charakter obiektów służących zakwaterowaniu. Ich liczba jest różna w zależności od gminy. I tak: w Como i Palermo podatek pobierany jest do maksymalnie 4 noclegów; w Bolonii i Lecce ${ }^{40}-$ do 5 noc-

37 Art. 2 ust. 4 uchwały Catanzaro.

38 Art. 2 ust. 1 uchwały Neapolu.

39 Art. 4 ust. 3 Regolamento dell'imposta comunale di soggiorno nella Città di Milano, approvato con deliberazione del Consiglio Comunale n. 19 dell'11 giugno 2012 con modificazione, https://www.comune.milano.it/documents/20126/0/Regolamento+Imposta+di+Soggiorno+2019.pdf/35039f68-716e-3296-3a70-b047eee43bf2?t=1556288943972; dostęp: 1.04.2019 r. (dalej: uchwała Mediolanu).

40 Art. 6 ust. 3 uchwały Lecce. 
legów; w Rawennie i Sienie ${ }^{41}$ - do 6 noclegów; we Florencji, Sorrento ${ }^{42}$, Pompeje $^{43}$, Cuneo ${ }^{44}$, Rimini ${ }^{45}$ - do 7 noclegów; w Bergamo ${ }^{46}$ i Taorminie - do 10 noclegów; Neapolu - do 14 noclegów. Dodatkowo w poszczególnych uchwałach znaleźć można regulacje, na podstawie których pobór podatku ograniczony został wyłącznie do sezonu turystycznego. Sytuacja taka ma miejsce zazwyczaj w niewielkich miejscowościach. Powyższe rozwiązania przyjęły m.in. Sorrento ${ }^{47}$, Positano ${ }^{48}$, Ravello ${ }^{49}$, gdzie obowiąz-

41 Regolamento dell'imposta di soggiorno nel Comune di Siena, approvato con deliberazione del Consiglio Comunale n. 196 del 13 dicembre 2011 con modificazioni, https:/ / www.citsnet.it/cits/images/documenti/siena_regolam_imposta_soggiorno.pdf [dostęp: 1.04.2019 r.].

42 Regolamento per la disciplina dell'imposta di soggiorno, approvato con deliberazione del Consiglio Comunale n. 99 del 29 novembre 2011, https:/ / trasparenza.comune. sorrento.na.it/archivio19_regolamenti_0_2567.html; dostęp: 1.04 .2019 r. (dalej: uchwała Sorrento).

${ }^{43}$ Art. 3 ust. 1 Regolamento comunale per la disciplina dell'imposta di soggiorno, approvato con deliberazione del Consiglio Comunale n. 52 del 21 dicembre 2017, http:/ / www.comune.pompei.na.it/aree-tematiche/imposta-di-soggiorno/ [dostęp: 1.04.2019 r.].

44 Art. 4 ust. 2 Regolamento comunale sull'imposta di soggiorno, approvato con deliberazione del Consiglio Comunale n. 26 del 29 marzo 2018, http:/ / www.comune.cuneo.it/ fileadmin/comune_cuneo/content/amm_organiz/attivita_promozionali_produttive/ De.C.O/Normativa_e_regolamenti/RegolamentoTassaSoggiorno.pdf; dostęp: 1.04.2019 r. (dalej: uchwała Cuneo).

45 Art. 2 ust. 4 Regolamento comunale per l'istituzione e l'applicazione dell'imposta di soggiorno, approvato con deliberazione del Consiglio Comunale n. 30 del 14 giugno 2012 con modificazioni, https://www.comune.rimini.it/sites/comune.rimini.it/files/regolamento_ids_da_2019.pdf; dostęp: 1.04.2019 r. (dalej: uchwała Rimini).

46 Art. 4 ust. 3 Regolamento dell'imposta di soggiorno nella Città di Bergamo, approvato con deliberazione del Consiglio Comunale n. 213 del 12 dicembre 2011, https:/ / www.comune.bergamo.it/action\%3Ac_a794\%3Aimposta.soggiorno; dostęp: 1.04 .2019 r. (dalej: uchwała Bergamo).

47 Art. 3 ust. 1 uchwały Sorrento.

48 Art. 3 ust. 1 Regolamento comunale per l'applicazione dell'imposta di soggiorno, approvato con deliberazione del Consiglio Comunale n. 37 del 29 dicembre 2017, https:/ / comune.positano.sa.it/wp-content/uploads/2018/01/Regolamento-comunale-per-1\%E2\% 80\%99applicazione-dell \% E2\% 80\% 99imposta-di-soggiorno.-Approvazione-deliberazione-del-Consiglio-Comunale-n.-37-del-29.12.2017.pdf [dostęp: 1.04.2019 r.].

49 Art. 6 Regolamento comunale dell'imposta di soggiorno, approvato con deliberazione del Consiglio Comunale n. 6 del 28 marzo 2018, http:/ / www.comune.ravello.sa.it/2018/ wp-content/uploads/2018/05/Regolamento-imposta-di-soggiorno-2018.pdf [dostęp: 1.04.2019 r.]. 
kowi podatkowemu podlegają nierezydenci przebywający tylko w okresie od 1 kwietnia do 31 października, a w Otranto ${ }^{50}$ lub Vasto ${ }^{51}$ podatek pobierany jest jedynie za pobyt pomiędzy 1 kwietnia a 30 września roku kalendarzowego.

Dokonanie klasyfikacji obiektów służących zakwaterowaniu, w których podatnik nocuje, jest o tyle istotne, iż w ustawie z 2011 r. wskazano na możliwość różnicowania wysokości podatku proporcjonalnie do jakości obiektu, przy czym określono jedynie maksymalną stawkę podatku, która nie może przekraczać 5 euro. Przypomnieć należy, że uchwały rady gminy wyróżniają obiekty hotelowe oraz pozahotelowe. Tym samym najwyższe stawki przewidziano dla obiektów hotelowych, w ramach których wysokość podatku dodatkowo jest różnicowana wedle standardu świadczonych usług noclegowych wyrażonego w liczbie posiadanych gwiazdek. Stąd też, jeżeli dana gmina zdecyduje się na zastosowanie maksymalnej stawki kwotowej wynoszącej 5 euro, to jest ona przewidziana dla pięciogwiazdkowych hoteli (sytuacja taka ma miejsce np. w Amalfi, Turynie czy Mediolanie). Niemniej jednak od powyższej reguły zdarzają się wyjątki. W Bolonii przyjęto zupełnie inny sposób różnicowania stawki podatku jej wysokość powiązano z ceną netto za nocleg w danym obiekcie ${ }^{52}$.

Ustawa z 2011 r. nie reguluje kwestii możliwych do zastosowania ulg podatkowych. Problematykę tę rozstrzygają rady gmin w podejmowanych przez siebie uchwałach. Polegają one na procentowym obniżeniu wysokości kwoty podatku. Ich charakter zależy od tradycji danej gminy lub przyjętej koncepcji rozwoju ${ }^{53}$. Dość często spotykaną ulgą jest obni-

50 Art. 3 ust. 3 Regolamento per l'applicazione dell'imposta di soggiorno, approvato con deliberazione del Consiglio Comunale n. 28 del 28 giugno 2011 con modificazioni, https:/ / www.comune.otranto.le.it/amministrazione/attivita/statuto-e-regolamenti/ item/regolamento-imposta-di-soggiorno-2 [dostęp: 1.04.2019 r.].

51 Art. 5 ust. 1 lit. e Regolamento dell'imposta di soggiorno, approvato con deliberazione di Consiglio Comunale n. 105 del 29 novembre 2013 con modificazione, http:/ / www.comune.vasto.ch.it/images/PDF/Statuto/SERVIZIOTRIBUTI/Regolamento-Imposta-di-Soggiorno.pdf; dostęp: 1.04.2019 r. (dalej: uchwała Vasto).

52 W Bolonii wyróżniono pięć progów cenowych, dla których przewidziano odpowiednią stawkę podatku. Dla ceny noclegu od 1 euro do 30,99 euro stawka podatku wynosi 1,50 euro; od 31 do 70,99 euro - 2,00 euro; od 71 do 120,99 euro - 3,00 euro; od 121 do 200,99 euro - 4 euro, ponad 201 euro - 5 euro. Natomiast dla kempingów i hosteli stawka wynosi 0,50 euro (art. 3 ust. 2 uchwały Bolonii).

53 W Wenecji zastosowanie mają ulgi od 20\% do 30\% w przypadku korzystania z noclegu we wskazanych obiektach położonych na wyspach znajdujących się na lagunie 
żenie podatku obciążającego młodzież w wieku szkolnym ${ }^{54}$ oraz uczestników zorganizowanych wycieczek szkolnych ${ }^{55}$. Preferencje mogą mieć zastosowanie do tych osób, które są uczestnikami zawodów sportowych lub innych imprez współorganizowanych przez gminę ${ }^{56}$. Dość często spotykaną ulgą jest obniżenie kwoty podatku tym nierezydentom, którzy korzystają z noclegu poza sezonem turystycznym. W takim przypadku stawka podatkowa najczęściej obniżana jest o 50\%. Co do zasady, tzw. okres poza sezonem trwa od 1 października do 31 marca. Jednakże rada gminy w Mediolanie w 2013 r. za miesiąc o niskim ruchu turystycznym uznała grudzień, natomiast w 2014 r. - sierpień. Ulgi mogą mieć także charakter prorodzinny. Niektóre gminy (np. Vasto) wprowadzają możliwość obniżenia wysokości podatku o $50 \%$ dla nierezydentów będących członkami rodzin wielodzietnych ${ }^{57}$. Obniżenie podatku ma miejsce także $\mathrm{w}$ tych gminach, które nie wprowadziły ograniczenia obowiązku podatkowego polegającego na ustaleniu maksymalnej liczby noclegów. Na przykład w Amalfi podatek obniżany jest o $50 \%$ za każdy następny dzień powyżej czwartego dnia pobytu ${ }^{58}$, a w Catanzaro - powyżej 7 noclegu ${ }^{59}$.

$\mathrm{W}$ ramach władztwa podatkowego, przyznanego włoskim gminom w szerokim zakresie, znajduje się także możliwość kształtowania zwolnień. Podobnie jak w przypadku ulg, także ten rodzaj elementu konstrukcyjnego podatku jest niezwykle różnorodny. Analizując poszczególne uchwały można wyróżnić kilka grup. Po pierwsze, preferencje moga być przyznane tym osobom, których przebywanie na terenie danej gminy nie do końca związane jest z ich wyborem. Do tej grupy w pierwszej

(art. 5 ust. 4 uchwały Wenecji). W Mediolanie stosuje się ulgę w wysokości 50\% w stosunku do podatników będących uczestnikami ważnych kongresów lub wystaw (art. 5 uchwały Mediolanu).

${ }^{54} \mathrm{~W}$ Wenecji obniża się podatek o 50\%, gdy podatnikiem jest osoba w wieku 10 do 16 roku życia (art. 5 ust. 4 uchwały Wenecji).

55 We Florencji obniża się podatek o $50 \%$ dla uczestników grup szkolnych przebywających w celach dydaktycznych (art. 6 ust. 1 uchwały Florencji). Podobna preferencja ma zastosowanie w Lecce (art. 5 ust. 1 lit. b uchwały Lecce).

56 We Florencji i w Lecce 50\% ulga w podatku przysługuje sportowcom do 16 roku życia biorących udział w zawodach sportowych i turniejach współorganizowanych przez gminę (art. 6 ust. 1 uchwały Florencji; art. 5 ust. 1 lit. c uchwały Lecce).

57 Ulga w postaci $50 \%$ kwoty podatku odnosi się do rodzin wielodzietnych i obowiązuje od trzeciego i następnego dziecka (art. 5 ust. 1 lit. g uchwały Vasto).

58 Art. 6 ust. 3 uchwały Amalfi.

59 Art. 5 ust. 3 uchwały Catanzaro. 
kolejności zaliczyć należy osoby, które przebywają w miejscowości, korzystając z opieki szpitalnej lub poddające się określonym zabiegom zdrowotnym lub rehabilitacyjnym. Dodatkowo zwolnienie przyznane zostaje także osobom towarzyszącym podczas pobytu w szpitalu (np. w Rimini ${ }^{60}$ czy Florencji $\left.{ }^{11}\right)$. Preferencja taka może zostać rozszerzona na więcej niż jedną osobę, np. gdy osobą poddaną hospitalizacji jest osoba niepełnoletnia. Zwolnienia odnoszące się do obojga rodziców lub innych opiekunów prawnych można spotkać m.in. w Bergamo, Bolonii, Florencji, Neapolu, Sienie, Taorminie ${ }^{62}$. Po drugie, zwolnione są osoby, których przebywanie związane jest z wykonywaniem określonego charakteru pracy na rzecz danej społeczności lokalnej. W uchwałach spotkać można zwolnienia osób zatrudnionych np. w policji, wojsku, straży pożarnej czy też innych służbach porządkowych, które podczas pobytu strzegą bezpieczeństwa publicznego, a także innych osób wykonujących na rzecz gminy lub społeczności lokalnej określone zadania (w tym także wolontariuszy ${ }^{63}$ ). Powyższe preferencje odnaleźć można m.in. w uchwałach Agrigento, Catanzaro, Mediolanu, Neapolu, Wenecji, Turynu, Werony, Sieny, Bergamo, Como czy Taorminy. Po trzecie, zwolnienie może odnosić się do osób, które przebywają w danej gminie ze względu na charakter wykonywanej pracy. Niewątpliwie do grupy tej zaliczyć należy kierowców autokarów turystycznych oraz osoby obsługujące grupy turystyczne ${ }^{64}$. Ten rodzaj zwolnienia zazwyczaj stosowany jest $\mathrm{w}$ miejscowościach atrakcyjnych turystycznie takich jak Ankona, Bergamo, Como, Lecce, Neapol, Siena, Rawenna, Taormina, Turyn, Wenecja lub Werona. Do omawianej grupy zwolnień przypisać należy także preferencje podatkowe mające zastosowanie w stosunku do tych osób, które przebywają tymczasowo na terenie gminy i są zatrudnione przez lokalne przedsiębiorstwa (nierzadko w sektorze turystyczno-gastronomicznym). Takie regulacje odnaleźć

${ }^{60}$ Art. 4 ust. 1 lit. c uchwały Rimini.

${ }^{61}$ Art. 5 ust. 1 lit. b uchwały Florencji.

${ }^{62} \mathrm{~W}$ niektórych gminach wprowadzony został jednak limit wieku dziecka, np. w Bergamo i Taorminie ze zwolnienia korzystają rodzice dziecka do lat 12 (art. 5 ust. 1 lit. d uchwały Bergamo; art. 3 ust. 5 uchwały Taorminy); w Bolonii od 1 kwietnia 2015 r. - rodzice dziecka do lat 14 (art. 2 ust. 4 lit. a uchwały Bolonii).

63 Art. 3 ust. 1 lit. f uchwały Cuneo.

${ }^{64} \mathrm{~W}$ stosunku do osób obsługujących grupy turystyczne wprowadzone zostały ograniczenia. Zwolnienie dla jednej osoby przysługuje, gdy grupa liczy 20 lub 25 osób. 
można w uchwałach Catanzaro, Sieny, Neapolu czy Rawenny ${ }^{65}$. Po czwarte, zwolnione z podatku są osoby, które przebywają na terenie danej gminy, jednakże charakter ich pobytu zbliżony jest do osób mających tam status rezydenta. Do tej grupy zwolnień zaliczyć należy uczniów i studentów pobierających naukę w szkołach powszechnych lub uniwersytetach. W praktyce zwolnienie to stosowane jest przez każdą gminę posiadającą status miasta uniwersyteckiego. Jednakże, aby skorzystać z omawianej preferencji należy być studentem miejscowego uniwersytetu (np. w Bolonii, Catanzaro, Genui, Florencji). Zdarzyć się jednak może, że uchwała wprowadza jedynie wymóg posiadania statusu studenta oraz odpowiedniego wieku, który co do zasady nie może przekroczyć 26 lat (np. regulacje taką przyjęła gmina Agrigento). Po piąte, przyczyną zwolnienia mogą być szeroko pojęte względy społeczne. W prawie każdej uchwale zwolnione z podatku są dzieci. Wprowadzany jest jednak limit wiekowy. W Neapolu i Mediolanie zwolnione są osoby do 18 roku życia, w Amalfi, Lecce, Wenecji - do 10, w Sienie, Taorminie i Florencji - do 12, w Genui, Bolonii, Weronie i Rawennie - do 14, natomiast w Bergamo - do 16 roku życia. Zwolnieniu podlegają także nierezydenci posiadający status osoby niepełnosprawnej. Natomiast w Neapolu z obowiązku zapłaty podatku zwolniono osoby posiadające status uchodźcy politycznego ${ }^{66}$.

\section{Podatek od zejścia z pokładu jako alternatywa dla podatku turystycznego}

Podnieść należy, że po dokonanej w 2012 r. nowelizacji ustawy z 2011 r. gminy włoskie będące wyspą lub na terenie, których znajdują się tak zwane małe wyspy (isole minori) mogą alternatywnie, zamiast podatku turystycznego, wprowadzić podatek od zejścia z pokładu (imposta di sbarco lub contributo di sbarco). Dla niektórych gmin ustanawianie powyższej daniny jest korzystniejsze od podatku turystycznego. Wynika to z faktu, że w zdecydowanej większości powierzchnia wysp jest nieduża, stąd też liczba obiektów służących zakwaterowaniu jest proporcjonalnie mniejsza. Zauważyć jednak należy, że ograniczony dostęp do obiektów służących

65 Zob. art. 4 ust. 1 lit. d uchwały Rawenny.

${ }^{66}$ Art. 7 lit. e uchwały Neapolu. 
zakwaterowaniu nie wpływa na zmniejszenie liczby osób odwiedzających gminę (wyspę) - zmienia się tylko charakter pobytu z kilkudniowego do jednodniowego. Sytuację taką można zaobserwować na Wyspach Tremiti, Capri i Ancapri czy też na Wyspach Liparyjskich. Wprowadzenie podatku od zejścia z pokładu (imposta di sbarco) rekompensuje w pewien sposób szybsze zużycie infrastruktury gminnej. Omawiana danina wliczana jest do ceny biletu wystawianego przez armatorów żeglugowych zapewniających połączenie wyspy ze stałym lądem. Stawki podatku określone są w stosownych uchwałach. Niektóre gminy różnicują wysokość podatku od tego, czy podróż na wyspę odbywa się w trakcie sezonu, czy poza sezonem turystycznym. Na przykład wyspa Pantelleria ustaliła, że w okresie od 1 lipca do 31 sierpnia danina wynosi 5 euro od każdego pasażera, natomiast $\mathrm{w}$ pozostałych miesiącach $-2,5$ euro $^{67}$. Podobne rozwiązanie ma zastosowanie na Wyspach Liparyjskich, z tym, że podatek w wyższej kwocie pobierany jest $\mathrm{w}$ okresie od 1 czerwca do 30 września ${ }^{68}$. W poszczególnych uchwałach zawarte zostały zwolnienia, które dotyczą m.in.: osób niebędących rezydentami podejmujących na terenie gminy pracę; osób będących podatnikami podatku od nieruchomości lub członkami ich rodziny (Pantelleria, Capri i Anacapri ${ }^{69}$, Ventotene ${ }^{70}$, Wyspy Liparyjskie);

67 Art. 3 ust. 1 Regolamento per l'applicazione del „Contributo di sbarco" e del „Contributo per l'accesso a zone disciplinate nella loro fruizione per motive ambientali, in prossimità di fenomeni attivi di origine vulcanica", approvato con deliberazione del Consiglio Comunale n. 19 del 31 marzo 2017, http:/ / www.comunepantelleria.it/atti/2017/DELIBERE\%20DI\%20CONSIGLIO/04-APRILE/regolamento\%20contributo\%20di \%20sbarco \% 20 aggiornato.pdf [dostęp: 1.04.2019 r.]. Wskazać ponadto należy, że gmina Pantelleria wprowadziła możliwość obniżenia podatku o 50\%. Z preferencji tej skorzystać mogą dzieci do lat 12, uczestnicy wycieczek szkolnych oraz osoby starsze.

68 Art. 3 ust. 2 Regolamento per l'istituzione e la disciplina del "Contributo di sbarco di accesso a zone disciplinate per motivi ambientali" n. 49 del 16 settembre 2016, http://www.comunelipari.gov.it/zf/index.php/servizi-aggiuntivi/index/index/idservizio/20043 [dostęp: 1.04.2019 r.].

69 Art. 4 ust. 1 Regolamento sul contributo di sbarco nell'Isola di Capri, approvato con deliberazione del Consiglio Comunale n. 99 del 30 novembre 2016, http:// www.capritourism.com/imgg/download/Comune \% 20Anacapri \%20regolamento \% 20 contributo \%20di\%20sbarco.pdf [dostęp: 1.04.2019 r.].

70 Art. 5 Regolamento comunale per la disciplina dell' imposta di sbarco, approvato con deliberazione del Consiglio Comunale n. 16 del 7 giugno 2012 e successivamente modificato con deliberazione del Consiglio Comunale n. 26 del 17 settembre 2012, https:/ / www.halleyweb.com/ c059033/zf/index.php/atti-generali/index/dettaglio-atto/atto/2 [dostęp: 1.04.2019 r.]. 
osób będących uczestnikami wycieczek szkolnych (Favignana ${ }^{71}$, Pantelleria); dzieci do 12 roku życia (Favignana); uczniów dojeżdżających do szkoły (Favignana, Pantelleria, Capri i Anacapri, Ventotene); osób niepełnosprawnych (Ventotene).

\section{Wnioski końcowe}

Przedstawione powyżej rozwiązania w zakresie kształtowania elementów konstrukcyjnych włoskiego podatku turystycznego mogą okazać się inspirujące przy ewentualnym wprowadzaniu zmian $\mathrm{w}$ polskiej opłacie miejscowej oraz uzdrowiskowej - zwłaszcza, że w pewnych aspektach uwypuklają one mankamenty polskich regulacji. W pierwszej kolejności należy, zwrócić uwagę na zakres podmiotowy. Wydaje się, że przepisy odnoszące się do polskich danin, wzorem włoskich rozwiązań, powinny wyraźnie wskazywać na nierezydenta (rozumianego jako osobę niemającą zamieszkania na terenie danej gminy) jako podmiot, który powinien być zobowiązany do uiszczenia jednej z dwóch opłat. Ponadto koniecznym jest doprecyzowanie zakresu czasowego pobytu, aby opłata nakładana była nie za każdą dobę, ale za każdą noc spędzoną w danej miejscowości. Jest to o tyle istotne, gdyż stosownie do aktualnie obowiązujących przepisów prawa przebywanie $\mathrm{w}$ danej miejscowości wyłącznie przez jedną dobę powoduje, że opłata miejscowa lub uzdrowiskowa nie powinna zostać uiszczona. Konsekwencją takiego stanu rzeczy, powinno być $\mathrm{z}$ kolei dookreślenie zakresu przedmiotowego, w taki sposób, aby pobyt $\mathrm{w}$ postaci noclegu miał miejsce wyłącznie $\mathrm{w}$ wymienionych obiektach zakwaterowania.

Dodatkowo analizując włoskie rozwiązania nie sposób nie zauważyć wadliwych regulacji zawartych w polskiej ustawie o podatkach i opłatach lokalnych odnoszących się do możliwości określania wysokości stawek. W Polsce, radzie gminy przysługuje jedynie ustalenie wysokości opłaty bez uwzględnienia rodzaju miejsca pobytu oraz okresu pobytu $\mathrm{w}$ danej

71 Art. 5 ust. 1 Regolamento per la disciplina del „Contributo di sbarco”, approvato con deliberazione del Consiglio Comunale n. 42 del 30 dicembre 2016, http://www.comune. favignana.tp.gov.it/zf/index.php/atti-generali/index/table-atti/table-atti-generali-public-page/1 [dostęp: 1.04.2019 r.]. 
miejscowości. Wydaje się, że wysokość stawek opłaty miejscowej i uzdrowiskowej powinna zostać uzależniona od rodzaju obiektu hotelowego i jego standardu. Ponadto należy zauważyć, że także katalog zwolnień powinien ulec przedefiniowaniu.

Słowa kluczowe: podatek turystyczny, opłata miejscowa, opłata uzdrowiskowa, podatki lokalne, Włochy

\section{Bibliografia}

\section{Źródła}

Ustawa z dnia 12 stycznia 1991 r. o podatkach i opłatach lokalnych, tekst jednolity: Dz. U. z 2019 r. poz. 1170.

Legge Costituzionale 26 febbraio 1948, n. 4, Statuto speciale per la Valle D'Aosta, Gazzeta Ufficiale n. 59 del 10 marzo 1948.

Legge Costituzionale 31 gennaio 1963, n. 1, Statuto speciale della Regione autonoma Friuli Venezia Giulia, Gazzetta Ufficiale n. 29 del 1 febbraio 1963.

Legge 11 dicembre 1910, n. 863, che dà facoltà ai Comuni di istituire una tassa di soggiorno, Gazzetta Ufficiale n. 294 del 20 dicembre 1910.

Regio Decreto-Legge 24 novembre 1938, n. 1926, Modificazioni concernenti l'ordinamento della imposta di soggiorno, di cura e turismo, Gazzetta Ufficiale n. 297 del 29 dicembre 1938.

Decreto del Presidente della Repubblica 30 maggio 1989, n. 223, approvazione del nuovo regolamento anagrafico della popolazione residente, Gazzetta Ufficiale $\mathrm{n} .132$ del 8 giugno 1989.

Decreto-Legge 2 marzo 1989, n. 66, Disposizioni urgenti in materia di autonomia impositiva degli enti locali e di finanza locale, Gazzetta Ufficiale n. 51 del 2 marzo 1989.

Decreto-Legge 31 maggio 2010, n. 78, Misure urgenti in materia di stabilizzazione finanziaria e di competitività economica, Gazzetta Ufficiale n. 176 del 30 luglio 2010.

Decrecto Legislativo 14 marzo 2011, n. 23, Disposizioni in materia di federalismo Fiscale Municipale, Gazzetta Ufficiale n. 67 del 23 marzo 2011.

Dectreto del Presidente della Repubblica 31 agosto 1972, n. 670, Approvazione del testo unico delle leggi costituzionali concernenti lo statuto speciale per il Trentino-Alto Adige, Gazzetta Ufficiale n. 301 del 20 novembre 1972.

Legge Regionale 29 agosto 1976, n. 10, Disciplina dell'imposta di soggiorno, Bollettino Ufficiale n. 46 del 26 ottobre 1976. 
Legge Regionale 28 luglio 2004, n. 16, Disciplina delle strutture ricettive dirette all'ospitalità, Bollettino Ufficiale della Regione Emilia-Romagna" n. 102 del 28 luglio 2004.

Legge Regionale 11 maggio 2006, n. 4, Disposizioni varie in materia di entrate, riqualificazione della spesa, politiche sociali e di sviluppo, Bollettino Ufficiale della Regione Sardegna n. 15 del 13 maggio 2006.

Legge Regionale 29 maggio 2007, n. 2, Disposizioni per la formazione del bilancio annuale e pluriennale della Regione (legge finanziaria 2007), Bollettino Ufficiale della Regione Sardegna n. 18 del 31 maggio 2007, Supplemento Ordinario n. 2.

Legge Regionale 12 novembre 2014, n. 32, Testo Unico in materia di strutture turistico ricettive e norme in materia di imprese turistiche, Bollettino Ufficiale n. 16 del 14 novembre 2014.

Legge Regionale 1 ottobre 2015, n. 27, Politiche regionali in materia di turismo e attrattività del territorio lombardo, Bollettino Ufficiale n. 40 del 2 ottobre 2015.

Legge Regionale 20 dicembre 2016, n. 86, Testo unico del sistema turistico regionale, Bollettino Ufficiale n. 57 del 28 dicembre 2016.

Legge Provinciale 11 giugno 2002, n. 8, Disciplina della promozione turistica in provincia di Trento, Bollettino Ufficiale n. 27 del 25 giugno 2002.

Legge Provinciale 16 maggio 2012, n. 9, Finanziamento in materia di turismo, Gazzetta Ufficiale 3 Serie Speciale - Regioni n. 25 del 30 giugno 2012.

Regolamento per l'istituzione e la disciplina del "Contributo di sbarco di accesso a zone disciplinate per motivi ambientali" n. 49 del 16 settembre 2016, http:/ / www.comunelipari.gov.it/zf/index.php/servizi-aggiuntivi/index/index/ idservizio/20043 [dostęp: 1.04.2019 r.].

Regolamento dell'imposta di soggiorno nella Città di Firenze, approvato con deliberazione del Consiglio Comunale n. 33 del 20 giugno 2011 con modificazioni, http://centroservizi.lineacomune.it/immagini/images/IMPOSTASOGGIORNO/firenze-1giugno/Regolamento_giugno2012.pdf [dostęp: 1.04.2019 r.].

Regolamento per l'applicazione dell'imposta di soggiorno, approvato con deliberazione del Consiglio Comunale n. 28 del 28 giugno 2011 con modificazioni, https:// www.comune.otranto.le.it/amministrazione/attivita/statuto-e-regolamenti/item/regolamento-imposta-di-soggiorno-2 [dostęp: 1.04 .2019 r.].

Regolamento per la disciplina dell'imposta di soggiorno, approvato con deliberazione del Consiglio Comunale n. 99 del 29 novembre 2011, https:// trasparenza.comune.sorrento.na.it/archivio19_regolamenti_0_2567.html [dostęp: 1.04.2019 r.].

Regolamento dell'imposta di soggiorno nella Città di Bergamo, approvato con deliberazione del Consiglio Comunale n. 213 del 12 dicembre 2011, https:// www.comune.bergamo.it/action\%3Ac_a794\%3Aimposta.soggiorno [dostęp: 1.04.2019 r.]. 
Regolamento dell'imposta di soggiorno nel Comune di Siena, approvato con deliberazione del Consiglio Comunale n. 196 del 13 dicembre 2011 con modificazioni, https://www.citsnet.it/cits/images/documenti/siena_regolam_ imposta_soggiorno.pdf [dostęp: 1.04.2019 r.].

Regolamento dell'imposta comunale di soggiorno nella Città di Genova, approvato con deliberazione del Consiglio Comunale n. 5 del 7 febbraio 2012 con modificazione, https://smart.comune.genova.it/system/files/regolamenti/ reg_imposta_soggiorno_2017_con_link_.pdf [dostęp: 1.04.2019 r.].

Regolameto per l'applicazione dell'imposta di soggiorno, approvato con deliberazione del Consiglio Comunale n. 349 del 27 febbraio 2012, http:/ / www. comune.torino.it/regolamenti/349/349.htm [dostęp: 1.04.2019 r.].

Regolamento dell'imposta di soggiorno nel Comune di Bologna, approvato con deliberazione del Consiglio Comunale n. 174 del 21 maggio 2012, http:// www.comune.bologna.it/media/files/regolamento_imposta_di_soggiorno_ odg_174_2012.pdf [dostęp: 1.04.2019 r.].

Regolamento comunale per la disciplina dell'imposta di sbarco, approvato con deliberazione del Consiglio Comunale n. 16 del 7 giugno 2012 e successivamente modificato con deliberazione del Consiglio Comunale n. 26 del 17 settembre 2012, https://www.halleyweb.com/c059033/zf/index.php/atti-generali/index/dettaglio-atto/atto/2 [dostęp: 1.04.2019 r.].

Regolamento dell'imposta comunale di soggiorno nella Città di Milano, approvato con deliberazione del Consiglio Comunale n. 19 dell'11 giugno 2012 con modificazione, https://www.comune.milano.it/documents/20126/0/Regolamento+Imposta+di+Soggiorno+2019.pdf/35039f68-716e-3296-3a70-b047eee43bf2?t=1556288943972 [dostęp: 1.04.2019 r.].

Regolamento comunale per l'istituzione e l'applicazione dell'imposta di soggiorno, approvato con deliberazione del Consiglio Comunale n. 30 del 14 giugno 2012 con modificazioni, https://www.comune.rimini.it/sites/comune.rimini.it/files/regolamento_ids_da_2019.pdf [dostęp: 1.04.2019 r.].

Regolamento sull'imposta di soggiorno, approvato con deliberazione del Consiglio Comunale n. 20 del 21 giugno 2012 con modificazioni, http:/ / www.comune.napoli.it/flex/cm/pages/ServeBLOB.php/L/IT/IDPagina/981 [dostęp: 1.04.2019 r.].

Regolamento dell'imposta di soggiorno, approvato con deliberazione del Consiglio Comunale, n. 61 del 12 luglio 2012, https://www.comune.verona.it/ media//Redazione\%20web/ente_comune/regolamenti/regolamento_imposta_di_soggiorno.pdf [dostęp: 1.04.2019 r.].

Regolamento comunale per l'applicazione dell'imposta di soggiorno, approvato con deliberazione del Consiglio Comunale n. 55 del 1 agosto 2012, https://www.comune.lecce.it/docs/default-source/regolamenti-comunali/ 
triuti-e-fiscalit\%c3\%a0-locale/regolamento-imposta-di-soggiorno-d-c-c-64_2018. pdf?sfvrsn=ee0fc0a8_8 [dostęp: 1.04.2019 r.].

Regolamento dell'imposta di soggiorno nel Comune di Taormina, approvato con deliberazione del Consiglio Comunale n. 80 del 6 novembre 2012, http:// www.comune.taormina.me.it/aree-tematiche/informazioni/imposta-di-soggiorno/pdf/regolamento-tassa-di-soggiorno-taormina.pdf [dostęp: 1.04.2019 r.]. Regolamento dell'imposta di soggiorno, approvato con deliberazione di Consiglio Comunale n. 105 del 29 novembre 2013 con modificazione, http:/ / www. comune.vasto.ch.it/images/PDF/Statuto/SERVIZIOTRIBUTI/Regolamento-Imposta-di-Soggiorno.pdf [dostęp: 1.04.2019 r.].

Regolamento per l'applicazione dell'imposta di soggiorno, approvato con deliberazione del Consiglio Comunale n. 29 del 29 settembre 2014, https:/ / www.amalfi.gov.it/wp-content/uploads/2014/10/Regolamento-per-lapplicazione-dellImposta-di-Soggiorno.pdf [dostęp: 1.04.2019 r.].

Regolamento sul contributo di sbarco nell'Isola di Capri, approvato con deliberazione del Consiglio Comunale n. 99 del 30 novembre 2016, http:// www.capritourism.com/imgg/download/Comune\%20Anacapri\%20regolamento\%20contributo\%20di\%20sbarco.pdf [dostęp: 1.04.2019 r.].

Regolamento per la disciplina del "Contributo di sbarco", approvato con deliberazione del Consiglio Comunale n. 42 del 30 dicembre 2016, http:// www.comune.favignana.tp.gov.it/zf/index.php/atti-generali/index/ table-atti/table-atti-generali-public-page/1 [dostęp: 1.04.2019 r.].

Regolamento per l'applicazione del "Contributo di sbarco" e del "Contributo per l'accesso a zone disciplinate nella loro fruizione per motive ambientali, in prossimità di fenomeni attivi di origine vulcanica", approvato con deliberazione del Consiglio Comunale n. 19 del 31 marzo 2017, http:// www.comunepantelleria.it/atti/2017/DELIBERE\%20DI\%20CONSIGLIO /04-APRILE/regolamento\%20contributo\%20di\%20sbarco\%20aggiornato.pdf [dostęp: 1.04.2019 r.].

Regolamento comunale per l'istituzione dell'imposta di soggiorno, approvato con deliberazione del Consiglio Comunale n. 125 del 30 ottobre 2017, https:/ /www. comune.catanzaro.it/ambiente/turismo/tassa-di-soggiorno/ [dostęp: 1.04.2019 r.].

Regolamento comunale per la disciplina dell'imposta di soggiorno, approvato con deliberazione del Consiglio Comunale n. 52 del 21 dicembre 2017, http:/ /www. comune.pompei.na.it/aree-tematiche/imposta-di-soggiorno/ [dostęp: 1.04.2019 r.].

Regolamento comunale per l'applicazione dell'imposta di soggiorno, approvato con deliberazione del Consiglio Comunale n. 37 del 29 dicembre 2017, https:/ / comune.positano.sa.it/wp-content/uploads/2018/01/Regolamento -comunale-per-1\%E2\%80\%99applicazione-dell\%E2\%80\%99imposta-di-soggiorno. -Approvazione-deliberazione-del-Consiglio-Comunale-n.-37-del-29.12.2017.pdf [dostęp: 1.04.2019 r.]. 
Regolamento comunale dell'imposta di soggiorno, approvato con deliberazione del Consiglio Comunale n. 6 del 28 marzo 2018, http:/ /www. comune.ravello.sa.it/ 2018/wp-content/uploads/2018/05/Regolamento-imposta-di-soggiorno -2018.pdf [dostęp: 1.04.2019 r.].

Regolamento comunale sull'imposta di soggiorno, approvato con deliberazione del Consiglio Comunale n. 26 del 29 marzo 2018, http://www.comune.cuneo.it /fileadmin/comune_cuneo/content/amm_organiz/attivita_promozionali_ produttive/De.C.O/Normativa_e_regolamenti/RegolamentoTassaSoggiorno.pdf [dostęp: 1.04.2019 r.].

Regolamento dell'imposta di soggiorno nella Città di Venezia, allegato alla deliberazione di consiglio Comunale n. 57 del 19 dicembre 2018, https:// www.comune.venezia.it/sites/comune.venezia.it/files/page/files/57_B\%20 Regolamento\%20Imposta\%20soggiorno.pdf [dostęp: 1.04.2019 r.].

Regolamento per l'applicazione dell' imposta di soggiorno, approvato con deliberazionedelConsiglio Comunalen.166del20 dicembre2018, http:/ / www.ravennaentrate.com/upload/Regolamento_delibera_CC_166_del_20-12-2018.pdf [dostęp: 1.04.2019 r.].

\section{Literatura}

Biagi B., M.G. Brandano, M. Pulina, La tassazione turistica: il caso della Sardegna, [w:] V. Ficari, G. Scanu (red.), "Tourism Taxation” sostenibilità ambientale e turismo fra fiscalità locale e competitività, Torino 2013.

Burzec M., Optata miejscowa jako danina nakładana na turystów, "Samorząd Terytorialny" 2019, nr 6.

Einaudi L., Il sistema tributario italiano, Torino 1939.

Gallo F., I principi fondamentali di coordinamento del sistema tributario nel federalismo fiscale, [w:] A. Uricchio (red.), Federalismo fiscale: evoluzione e prospettive, Bari 2013.

Giovannini A., Sul federalismo fiscale che non c'èe, „Diritto e Pratica Tributaria” 2012, t. 83 , nr 6 .

Ielo G., Il federalismo fiscale municipale, Milano 2011.

Kasprzak G., Zastapienie opłaty miejscowej optatą turystyczna - postulaty "de lege ferenda", ,Przegląd Podatków Lokalnych i Finansów Samorządowych” 2017, nr 8.

Krupa-Dąbrowska R., W Polsce danina jak we Włoszech, "Rzeczpospolita” z dnia 27 marca 2018 r. (dodatek Życie Regionów), https://regiony.rp.pl/ archiwum/5338-w-polsce-danina-jak-we-wloszech [dostęp: 1.04.2019 r.].

Morselli E., Le imposte in Italia, Padova 1956.

Morselli E., Sistema tributario Italiano. L'ordinamento delle imposte, Padova 1939.

Uricchio A., Il federalismo della crisi o la crisi del federalismo? Dalla legge delega 42/2009 ai decreti attuativi e alla manovra Salva Italia, Bari 2012. 


\section{TOURISM TAX IN ITALY}

\section{Sum mary}

This article elaborates upon the Italian tourism tax which is imposed on individuals who visit tourist attractions temporarily. In order to accurately present the essential elements of the structure of the above tax, several dozen resolutions of Italian municipal councils were analysed. The aim of the study is to indicate varied possibilities of shaping the structural elements of taxes imposed on tourists. This is important because in some respects Italian regulations highlight the shortcomings of Polish law on the basis of which fees are imposed on tourists

Key words: tourism tax, visitor fee, spa fee, local taxes, Italy

\section{КОНЦЕПЦИЯ ТУРИСТИЧЕСКОГО НАЛОГА, ВЗИМАЕМОГО В ИТАЛИИ}

\section{Резюме}

В статье рассматривается туристический налог, взимаемый в Италии с лиц, временно пребывающих в туристических населенных пунктах. Чтобы точно представить отдельные структурные элементы вышеупомянутого налога, были проанализированы несколько десятков постановлений муниципальных советов Италии. Цель исследования - показать различные возможности формирования структурных элементов налога, взимаемого с туристов. Это существенно, поскольку в некоторых аспектах итальянские нормативные акты подчеркивают недостатки польского законодательства, на основании которого взимаются туристические оплаты.

Ключевые слова: туристический налог, местный сбор, курортный сбор, местные налоги, Италия 